\title{
Overexpression of leucocyte common antigen (LAR) P-subunit in thyroid carcinomas
}

\author{
N Konishi*, , K Tsujikawa ${ }^{2}$, H Yamamoto ${ }^{2}$, E Ishida', M Nakamura', K Shimada', K Yane ${ }^{3}$, H Yamashita ${ }^{4}$ \\ and $\mathbf{S}$ Noguchi ${ }^{4}$
}

'Department of Pathology, Nara Medical University, 840 Shijo-cho, Kashihara, Nara 634-852 I, Japan; ²Department of Immunology, Graduate School of Pharmaceutical Science, Osaka University, Yamadaoka I-6, Suita, Osaka 565-087I, Japan; ${ }^{3}$ Department of Otolaryngology, Nara Medical University, 840 Shijo-cho, Kashihara, Nara 634-852 I, Japan; ${ }^{4}$ Noguchi Thyroid Clinic and Hospital Foundation, Noguchinakamachi 6-33, Beppu, Oita 874-0932, Japan

Protein tyrosine phosphatase (PTPase) dephosphorylation and protein tyrosine kinase (PTKs) phosphorylation of key signal transduction proteins may be regulated by extracellular signals, making PTPases important in the regulation of cell proliferation. Leucocyte common antigen (LAR), a receptor-like PTPase, consists of E-subunit, containing the cell adhesion molecule-like receptor region, and P-subunit specific for a short segment of the extracellular region, the transmembrane peptide, and two cytoplasmic PTPase domains. We produced a monoclonal antibody against the LAR P-subunit for immunohistochemical screening of LAR expression in normal and tumourous tissues. Gliomas and gastric, colorectal, lung, breast and prostate cancers showed weak and relatively infrequent expression. Intense and diffuse expression, however, was detected in 95\% (227 out of 239) of thyroid carcinomas, but only 12\% (22 out of 128) of adenomas and no cases of benign thyroid disease were immunopositive. In contrast to broad staining in carcinomas, LAR expression in thyroid adenomas was often found in small focal or locally invasive areas. Western blot analysis similarly detected LAR P-subunit protein in thyroid carcinomas, but not in normal tissues. We believe this to be the first demonstration of LAR overexpression in thyroid carcinoma and may help to elucidate the role of PTPases in the development of malignancy.

British Journal of Cancer (2003) 88, 1223 - 1228. doi:I0.1038/sj.bjc.6600876 www.bjcancer.com

(C) 2003 Cancer Research UK

Keywords: LAR; P-subunit; PTP; thyroid carcinoma; immunohistochemistry

Protein tyrosine phosphatases (PTPases) are important regulators in the reversible tyrosine phosphorylation of cellular protein via their interactions with protein tyrosine kinases (PTKs). Many oncogenes encode PTKs that participate in a large set of cellular events, such as migration, proliferation, differentiation and transformation, by regulating tyrosine phosphorylation of cellular proteins (Chernoff, 1999). The observation that PTPase can counteract PTK has led to the hypothesis that certain PTP genes might behave as tumour suppressor genes (Hunter, 1989). The fact that expression of certain PTPases is upregulated in hepatoma cells and in breast and glial tumours lends weight to the hypothesis and has identified some specific PTPases as candidates that might influence oncogenic transformation and tumour growth (Zhai et al, 1993; Wiener et al, 1994; Elson and Leder, 1995; Li et al, 1996; Norman et al, 1998).

To date, PTPases are structurally divided into intracellular PTPases and transmembrane receptor-like PTPases (Walton and Dixon, 1993; Neel and Tonks, 1997). Although intracellular PTPases possess only one PTPase domain, receptor-like PTPases have two cytoplasmic PTPase domains repeated in tandem. Among the receptor-like PTPases, leucocyte common antigen (LAR) consists of two noncovalently bound subunits, the extracellular

*Correspondence: Dr N Konishi; E-mail: nkonishi@naramed-u.ac.jp Received 17 October 2002; revised 23 December 2002; accepted 10 January 2003
(E) subunit and the phosphatase (P) subunit. The $150-\mathrm{kDa} E-$ subunit is composed of three Ig domains and eight Fn III domains, whereas the $85-\mathrm{kDa}$ P-subunit has a short extracellular domain, a transmembrane domain and two tandemly repeated PTPase domains, 1 and 2 (Streuli et al, 1992, 1998; Tsujikawa et al, 2001). Previous investigations suggest that domain 2 is structurally very similar to domain 1 and that its function may be to regulate the catalytic activity or specificity of domain 1 (Krueger et al, 1990; Streuli et al, 1990; Wang and Pallen, 1991; Nam et al, 1999). LAR has been reported to play a regulatory role in insulin signalling via the extracellular and two PTPase domains of the P-subunit (Hashimoto et al, 1992; Zhang et al, 1994; Serra et al, 1995; Tsujikawa et al, 2001). Analysis of LAR mutant proteins suggests that domain 1 is responsible for insulin receptor dephosphorylation, while domain 2 functions in recognition of the phosphorylated insulin receptor.

Although increased expression of LAR has been reported in breast cancer and in pheochromocytoma (Yang et al, 1999, 2000), the antibody used in these studies was raised against the E-subunit, rather than the P-subunit. To address the possibility that the LAR P-subunit might exert PTP-influencing oncogenic activity, we immunohistochemically screened the distribution of the P-subunit in both normal tissues and in various human tumours, subsequently concentrating on a large series of thyroid tumours in which overexpression of LAR P-subunit apparently distinguished malignant from benign disease. 


\section{MATERIALS AND METHODS}

\section{Tissue specimens}

All normal tissues examined were obtained from three autopsy cases. Tumour samples were obtained from surgery cases and included 13 gliomas, 10 meningiomas, 21 thyroid carcinomas, 16 gastric cancers, 26 colorectal cancers, 20 lung cancers, 20 breast cancers, eight hepatocellular carcinomas, 21 renal cell carcinomas and 32 prostate cancers. No chemotherapy was instituted before tumour excision. We also obtained additional thyroid tumours and samples of benign thyroid diseases obtained from surgical cases, which included 211 papillary carcinomas, 28 follicular carcinomas, two anaplastic carcinomas, two medullary carcinomas, 128 follicular adenomas, five nodular goiters, seven specimens from patients suffering from Basedow's disease (diffuse toxic goiters) and six cases of Hashimoto's thyroiditis. Tissue specimens were fixed in $10 \%$ neutral-buffered formalin and embedded in paraffin, and contiguous sections cut at $4 \mu \mathrm{m}$ for $\mathrm{H} \& \mathrm{E}$ staining and immunohistochemical analyses. Additional portions of thyroid tumours and samples of benign disease were frozen at $-80^{\circ} \mathrm{C}$ for later Western blot analysis.

\section{Preparation of anti-LAR P-subunit monoclonal antibody}

Glutathione-S-transferase-LAR fusion protein (GST-LAR) was employed as an immunogen. Escherichia coli AD202 was transformed with the pGEX-2T expression vector (Amersham Bioscience Corp., Piscataway, NJ, USA), which was incorporated to its BamHI/Eco RI site with cDNA corresponding to 607 amino acids spanning from the end of the transmembrane region of the LAR P-subunit (amino-acid residues 1275-1881) through the entire cytoplasmic region. BALB/c mice were immunised four times at approximately 2 -week intervals with $50 \mu \mathrm{g}$ of the fusion proteins. At 4 days after the last immunisation, splenocytes from mice with elevated antibody titres were fused with cells from the BALB/cderived myeloma cell stain NS1 and the resulting hybridomas were cloned using the ClonaCell ${ }^{\mathrm{TM}}-\mathrm{HY}$ Hybridoma Cloning Kit (StemCell Technologies, Inc., Vancouver, Canada). We used ELISA to screen the culture supernatant of the cloned hybridoma using the recombinant GST-LAR cytoplasmic domain fusion proteins. The specificity of the anti-LAR P-subunit monoclonal antibody, which we designated YU1, was further confirmed by Western blotting on cell lysates from LAR-transfected COS-7 cells (Tsujikawa et al, 2001).

\section{Immunoblotting}

Three representative frozen samples were divided into cancerous area and the corresponding normal tissue as positive and negative controls. The $300 \mu \mathrm{g}$ of proteins obtained from cell lysates of frozen samples were transferred from SDS-polyacrylamide gels to nitrocellulose membranes (Schleicher \& Schuell Bio Science, Keene, NH, USA) and endogenous enzyme activity blocked with $3 \%$ bovine serum albumin (BSA) TBS-T (20 mM Tris- $\mathrm{HCl} \mathrm{pH} 8.0,137 \mathrm{~mm} \mathrm{NaCl}$ and $0.1 \%$ Tween 20). The membranes were then incubated with $0.2 \mu \mathrm{g} \mathrm{ml}^{-1}$ of the anti-LAR P-subunit monoclonal antibody at room temperature for $1 \mathrm{~h}$, then washed three times with TBS-T. To detect antibody binding, the membranes were exposed to horseradish peroxidase (HRP)-conjugated anti-rabbit IgG (Santa Cruz Biotech, Inc., Santa Cruz, CA, USA) diluted in TBS-T and incubated at room temperature for $1 \mathrm{~h}$. After three washings in TBS-T, bound HRP conjugates were visualised with an enhanced chemiluminescent reagent (Wako Pure Chemical, Industries, Ltd, Osaka, Japan).

\section{Immunohistochemistry}

Unstained formalin-fixed tissue sections were probed for antibody reactivity using the streptavidin-biotin (SAB) method as follows: sections were deparaffinised and endogenous peroxidase was blocked using $0.3 \%$ hydrogen peroxidase in methanol followed by heating for $5 \mathrm{~min}$ in $10 \mathrm{mmoll}^{-1}$ of sodium citrate buffer ( $\mathrm{pH} \mathrm{6.0)}$ in a pressure cooker, then rinsed with phosphate-buffered saline (PBS) and incubated for $20 \mathrm{~min}$ with dilute normal rabbit serum. Sections were incubated again at room temperature for $90 \mathrm{~min}$ with our anti-LAR P-subunit monoclonal antibody at a concentration of $0.1 \mu \mathrm{g} \mathrm{ml}^{-1}$. Tissue sections were then exposed to biotinlabelled rabbit anti-mouse IgG for $30 \mathrm{~min}$, followed by the binding reactions using a Histofine SAB-PO kit (Nichirei, Tokyo, Japan). Copious washing with PBS between each step was essential. The peroxidase reactions were visualised by exposure to a solution of 3 , $3^{\prime}$-diaminobenzidine tetrahydrochloride in $0.01 \%$ hydrogen peroxide and counterstained with haematoxylin for microscopic evaluation. Identically treated specimens of thyroid cancer and the normal thyroid, which were immunopositive or negative for Western blotting, were used for the positive and negative controls.

In evaluating the immunostaining, we selected three areas within each stained lesion and counted the number of immunoreactive cells in fields of at least 200 tumour cells at a magnification of $\times 200$. The relative degree of immunostaining was recorded as $(-)$ when less than $20 \%$ of cells were positive, as $(+)$ when $20-50 \%$ of cells were positive and as $(++)$ when over $50 \%$ of cells were positive. Appropriate positive and negative controls were also included and evaluated in the same manner. Statistical analyses were carried out using Fisher's exact test supplemented by the Bonferroni procedure, a method that decreases the $\alpha$ level by dividing $\alpha$ by the number of comparisons made. Results were considered significant at $P<0.05$.

\section{RESULTS}

Leucocyte common antigen is synthesised as an approximately $200-\mathrm{kDa}$ precursor protein that is cleaved by an endogenous protease into two subunits, the $150-\mathrm{kDa}$ E-subunit and the $85-\mathrm{kDa}$ P-subunit (Tsujikawa et al, 2001). The anti-LAR P-subunit monoclonal antibody, designated YU1, detected $200-$ and $85-\mathrm{kDa}$ protein bands, which correspond precisely to the precursor protein and its P-subunit, respectively (Figure 1).

To identify the distribution of the LAR P-subunit in normal tissues, we screened the expression in almost all organs of the body. Although less than $20 \%$ of cells were positive, LAR P-subunit expression was detected in heart (three out of three), the hepatocytes of the liver (three out of three), renal tubular epithelium (three out of three), the exocrine cells of the pancreas (three out of three), stomach, small and large intestine (three out of three), the ganglia (two out of two) and in testicular tissue, including the seminiferous tubules and Leydig's cells (two out of three). Normal thyroid glands were very weakly positive in two of three cases. The only strongly positive cells were the bronchial cells of the lung (three out of three, data not shown).

Table 1 illustrates the immunohistochemical detection of YU1 expression in various types of human tumours. All thyroid cancers examined were positive, with the 13 cases of papillary carcinomas showing a signal significantly stronger $(P<0.001)$ than that seen in any other tumour type. Although the normal gastrointestinal mucosal glands exhibited very weak reactivity to YU1, gastric and colorectal cancers showed a diffuse staining pattern (Figure 2A). Two of 20 cases of lung cancer, adenocarcinomas (10\%) were focally positive for YU1 (Figure 2B). Each of the three cases of YU1-positive breast cancer (three of 20 cases, or 15\%) was histologically invasive ductal carcinoma (Figure 2C). Only two of 32 prostate cancers $(6.25 \%)$ were immunopositive; one case 
histologically appeared to be potentially metastatic (Figure 2D) and the other was immunoreactive only in frankly invasive areas.

Owing to the striking strong immunoreactivity of the thyroid cancers, we turned our attention to this apparently specific expression of LAR P-subunit in thyroid lesions, examining a large and varied series of thyroid tumours and diseases. Table 2

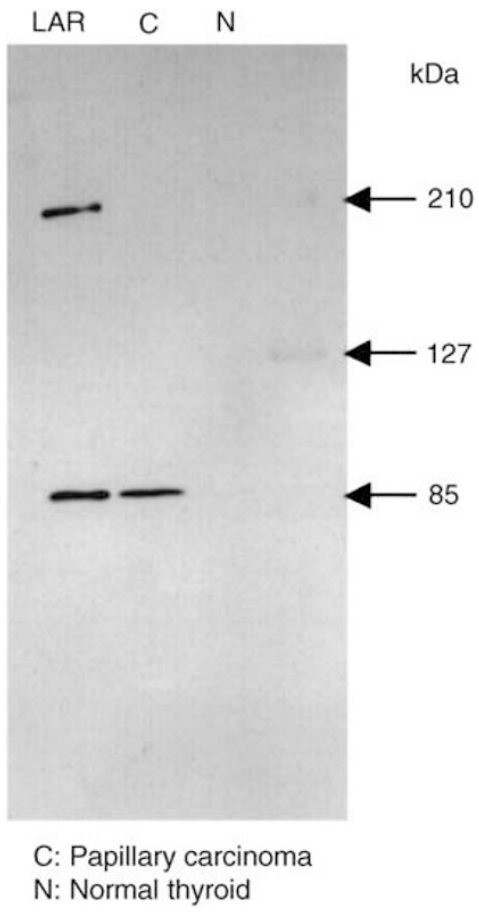

Figure I Western blot analysis of YUI expression in thyroid carcinoma and in corresponding normal tissues. A weight of $300 \mu \mathrm{g}$ of each protein was loaded on polyacrylamide gels and transferred to nitrocellulose membrane. Leucocyte common antigen precursor and P-subunit are shown in the left lane at 200 and $85 \mathrm{kDa}$, respectively. summarises the results of YU1 immunostaining in thyroid tissues. As can be seen, papillary and follicular carcinomas stained more strongly and more frequently than any other tumour type (Figure $3 \mathrm{~A}$ and $\mathrm{B}$ ). The limited number of anaplastic and medullary carcinomas were negative for YU1 as were the cases of nodular goitre, Basedow's disease and Hashimoto's thyroiditis. Of the 128 cases of histologically benign thyroid adenomas, only $22(17.2 \%)$ stained positive. Fully half of these YU1-positive adenomas exhibited focal, as opposed to diffuse, immunoreactivity (Figure 3C); however, the other half of these cases (11 out of 22) showed invasive growth into the capsule, but had not spread into vessels or lymph channels (Figure 3D).

Figure $3 \mathrm{~A}$ also demonstrates the very weak to nonexistent staining of normal follicular cells. The expression pattern of YU1 in papillary carcinoma was generally diffuse and intense in

Table I Expression of LAR P-subunit (YUI) in human tumours

\begin{tabular}{|c|c|c|c|c|c|}
\hline \multirow[b]{2}{*}{ Tumour } & \multirow[b]{2}{*}{$\begin{array}{l}\text { No. of } \\
\text { cases }\end{array}$} & \multicolumn{3}{|c|}{ Immunoreactivity } & \multirow[b]{2}{*}{$\begin{array}{c}\text { Percentage of } \\
\text { positivity }\end{array}$} \\
\hline & & $(-)$ & $(+)$ & $(++)$ & \\
\hline \multicolumn{6}{|l|}{ Brain tumour: } \\
\hline Glioma & 13 & 12 & I & 0 & 7.7 \\
\hline Meningioma & 10 & 10 & 0 & 0 & 0 \\
\hline Thyroid carcinoma & 21 & 0 & 8 & 13 & 100 \\
\hline Gastric cancer & 16 & 12 & I & 0 & 6.3 \\
\hline Colorectal cancer & 26 & 16 & 10 & 0 & 38.5 \\
\hline Lung cancer & 20 & 18 & 2 & 0 & 10.0 \\
\hline Breast cancer & 20 & 17 & 3 & 0 & 15.0 \\
\hline Hepatocelluar carcinoma & 8 & 8 & 0 & 0 & 0 \\
\hline Renal cell carcinoma & 21 & 21 & 0 & 0 & 0 \\
\hline Prostate cancer & 32 & 30 & 2 & 0 & 6.3 \\
\hline
\end{tabular}

Immunoreactivity was expressed as: $(-)<20 \%$ of cells immunopositive; $(+) 20-$ $50 \%$ of cells immunopositive; $(++)>50 \%$ of cells immunopositive.
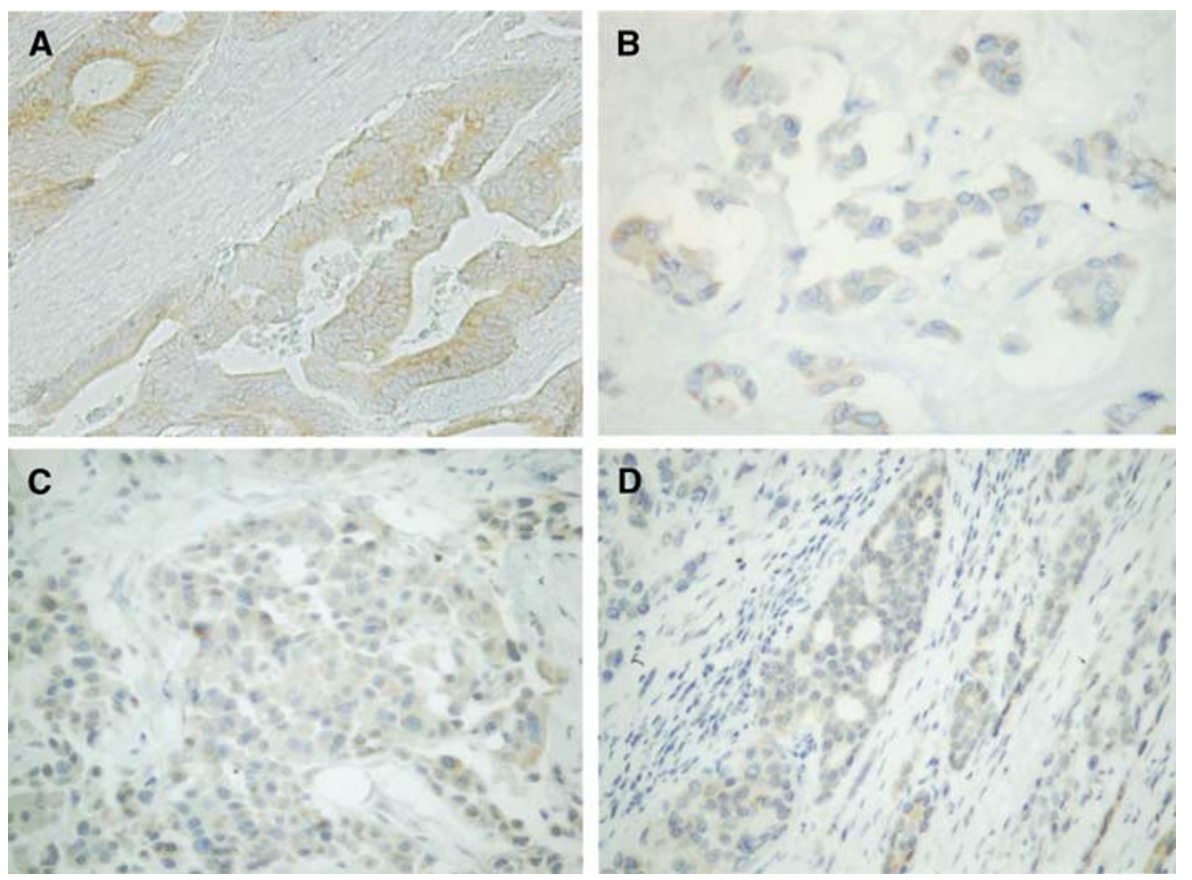

Figure 2 Immunohistochemical expression of LAR P-subunit (YUI) in human tumours. All cases were judged as $(+) .(\times 200)($ A $)$ colorectal cancer; $($ B $)$ poorly differentiated lung adenocarcinoma; $(\mathbf{C})$ invasive ductal breast carcinoma; (D) prostate cancer, metastatic site. 
cytoplasm with only occasional nuclear staining. We also confirmed that what we saw was indeed expression of the LAR P-subunit in thyroid papillary carcinomas and in the corresponding normal tissues by Western blot analysis (Figure 1). YU1 was strongly expressed in $41.2 \%$ of tumours (87 of 211), and moderately positive in $54.5 \%$ of tumours (115 of 211 ); the remaining $4 \%$ of tumours (nine of 211 ) examined demonstrated little to no immunoreactivity. However, five of these nine immunonegative tumours were pretreated with Plank Rychlo solution or ethylenediamine tetraacetate (EDTA) for decalcification, which might have affected their ability to express YU1. However, EDTA treatment was not a factor for the three immunonegative follicular carcinomas. Fully $89.3 \%$ of follicular carcinomas (25 of 28 ) expressed YU1 to some extent, with $21 \%$ (six of 28) demonstrating strong expression and 67.9\% (19 of 28) displaying moderate expression. Only $11 \%$ of these tumours were

Table 2 Expression of LAR P-subunit (YUI) in thyroid tumours and diseases

\begin{tabular}{|c|c|c|c|c|c|}
\hline \multirow[b]{2}{*}{ Thyroid tumour } & \multirow[b]{2}{*}{$\begin{array}{l}\text { No. of } \\
\text { cases }\end{array}$} & \multicolumn{3}{|c|}{ Immunoreactivity } & \multirow[b]{2}{*}{$\begin{array}{c}\text { Percentage of } \\
\text { positivity }\end{array}$} \\
\hline & & $(-)$ & $(+)$ & $(++)$ & \\
\hline Papillary carcinoma & 211 & 9 & 115 & 87 & 95.7 \\
\hline Follicular carcinoma & 28 & 3 & 19 & 6 & 89.3 \\
\hline Anaplastic carcinoma & 2 & 2 & 0 & 0 & 0 \\
\hline Medullary carcinoma & 2 & 2 & 0 & 0 & 0 \\
\hline Follicular adenoma & 128 & 106 & 21 & I & 17.2 \\
\hline Nodular goiter & 5 & 5 & 0 & 0 & 0 \\
\hline Basedow's disease & 7 & 7 & 0 & 0 & 0 \\
\hline Hashimoto's thyroiditis & 6 & 6 & 0 & 0 & 0 \\
\hline
\end{tabular}

Immunoreactivity was expressed as: $(-)<20 \%$ of cells immunopositive; $(+) 20-$ $50 \%$ of cells immunopositive; $(++)>50 \%$ of cells immunopositive. negative. The frequency of YU1 expression in papillary and follicular carcinomas was significantly different from that seen in both anaplastic and medullary carcinomas $(P=0.017)$ and in benign diseases $(P<0.001)$. There were no significant differences apparent between age or sex and immunohistochemical expression of YU1 (data not shown).

\section{DISCUSSION}

In 1992, Streuli et al (1992) reported that the LAR E-subunit was shed from the surface of HeLa cells in culture. Subsequent investigations on LAR expression in mammalian tumours and cell lines, therefore, involved the use of antibodies raised against the LAR E-subunit (Li et al, 1996; Yang et al, 1999, 2000) with largely negative results in the tissues examined. Here we show that not only is the LAR P-subunit expressed weakly in a number of normal and tumourous human tissues but also that protein levels are markedly increased in thyroid carcinoma, particularly in malignant papillary type cancers. The strong LAR P-subunit expression seen in thyroid carcinoma at significantly high frequencies contrasts with the relatively lower expression frequencies exhibited by other types of tumours and parallels previous data on PTPase expression in tumours (Zhai et al, 1993; Wiener et al, 1994; Elson and Leder, 1995; Li et al, 1996; Norman et al, 1998; Yang et al, 1999, 2000). Further, our findings are consistent with theories linking changes in PTPase expression to thyroid tumorigenesis.

It is fairly clear that two kinds of function are carried out by PTPases acting in concert with receptor PTKs (Villa-Moruzzi et al, 1998). The first function lies in the positive regulation of signalling pathways; PTPases bind the phosphorylated receptor or adaptor, which then become functional towards their substrates. The Src homology 2 (SH2) domain-containing PTP, SHP2, thus has a positive effect on cellular signalling (Tonks and Neel, 1996). Overexpression of PTP $\alpha$ is also necessary for the dephosphorylation and activation of the Src kinase (Zheng et al, 1992). Abnormal expression of PTK genes, such as insulin-like growth factor
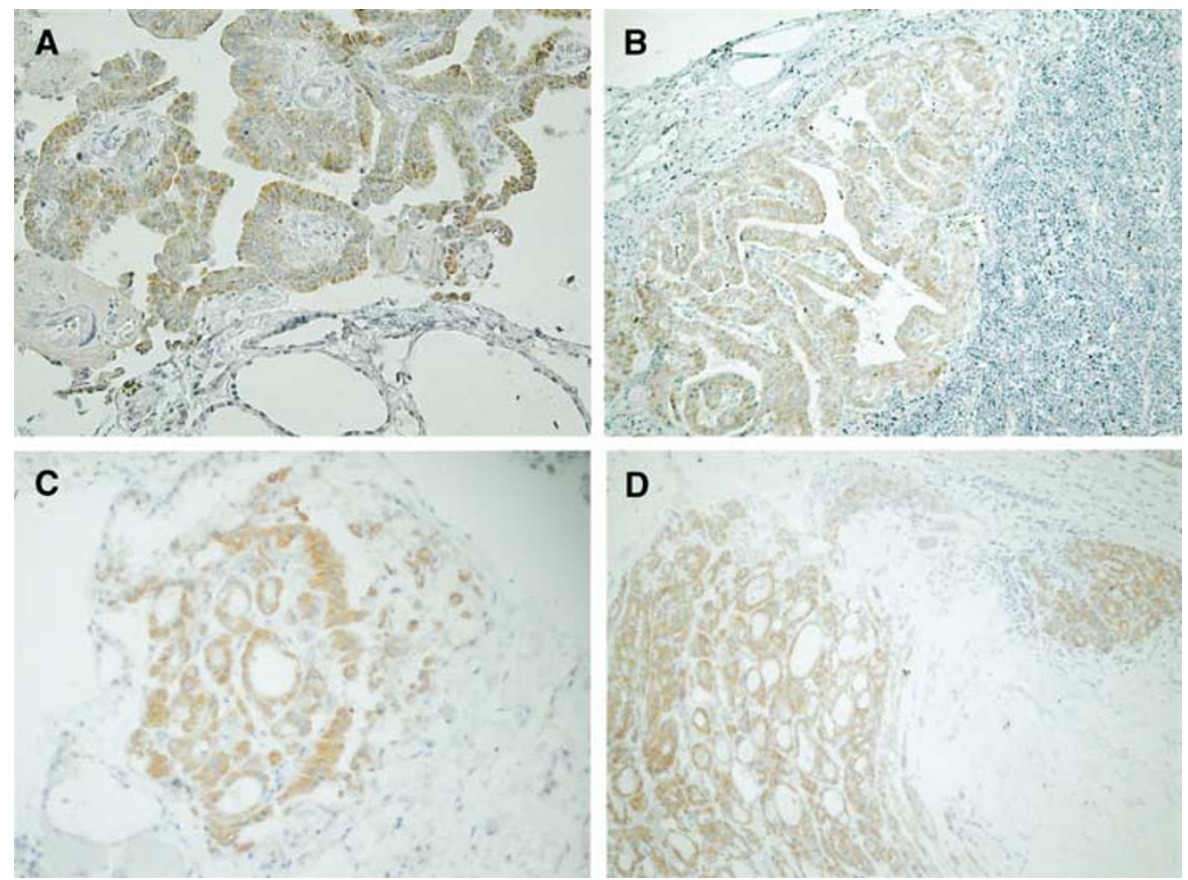

Figure 3 Immunohistochemical expression of the LAR P-subunit (YUI) in thyroid tumours. (A) papillary carcinoma, judged as (++), while the normal thyroid glands were negative $(\times 100)$, (B) papillary carcinoma, metastatic to lymph node $(\times 100)$, $(\mathbf{C})$ follicular adenoma showing focally positive immunostaining, judged as $(+)$ because positive tumour cells were $20-50 \%$ in the lesion $(\times 100)$, (D) follicular adenoma showing strong positive staining in invasive areas (diagnosed as invasive adenoma) $(\times 40)$. 
receptor (IGF-IR), epidermal growth factor receptor (EGFR), focal adhesion kinase (FAK), or the proto-oncogenes RET and NyK/mer, has been shown to correlate with progression in a variety of tumours (Luttrell et al, 1994; Liu et al, 1995; Resnik et al, 1998). A number of tyrosine kinase genes are, in fact, expressed in thyroid, breast and prostate cancers (Weier et al, 2001). It is possible that our demonstrations of LAR overexpression in some other types of tissues and tumours may be because of its role in dephosphorylation of receptor PTKs.

The second function of PTPases is negative signal transduction. PTPases contribute to the return to a normal functional state by dephosphorylating the receptor PTK; this is a major function of the receptor-like PTPases. Overexpression of LAR downregulates insulin-stimulated cellular responses in hepatoma cells (Li et al, 1996), suggesting that LAR acts as a physiological modulator. Phosphorylation may also regulate tumour cell adhesion molecules. Loss of these molecules has been correlated with increased tumour invasiveness and change in phenotype (Bukholm et al, 1998). Such molecules, including p120, catenin, E-cadherin, $\gamma$ catenin (plakoglobin) and $\beta$-catenin, are apparently regulated by tyrosine phosphorylation (Kanner et al, 1991; Hinck et al, 1994; $\mathrm{Xu}$ and Carpenter, 1999). LAR expression was evidently regulated by contact inhibition via E-cadherin-dependent cell-cell communication in an in vitro study (Symons et al, 2002). Although we could not find any correlation between LAR expression and tumour differentiation in this study, expression may not be because of phosphorylation mediated in this particular fashion.

The RET gene codes for a transmembrane tyrosine kinase that displays a cadherin-like domain and a cysteine-rich motif in the extracellular region. Rearrangement of the RET tyrosine-kinase receptor with different genes, especially RET/PTC1 and PTC3 generated by the fusion of RET to the $H 4$ or $R F G$ genes, respectively, is frequently found in thyroid papillary carcinoma, particularly in childhood radiation-induced thyroid cancers (Bongarzone et al, 1994; Santoro et al, 1994; Nikiforov et al, 1997; Jhiang, 2000). A recent study demonstrated that LAR overexpression decreased the oncogenic activity of a RET/MEN2A mutation when LAR and RET were cotransfected with a MEN2A or MEN2B mutation into an NIH3T3 cell line, possibly owing to interference with RET dimerisation (Qiao et al, 2001). The phenomenon was observed in both an in vitro colony formation assay as well as in an in vivo tumorigenicity assay using SCID mice. Interestingly, RET/PTC and the RET/MEN2A oncoproteins have constitutive kinase activity consequent to ligand-independent dimerisation (Monaco et al, 2001). We therefore suggest that LAR overexpression may affect RET/PTC dimerisation as well as kinase activity, and lead to reduced oncogenic potential, especially in papillary carcinoma.

A number of diagnostic markers have been reported in thyroid neoplasia. Recent interest has focused on the expression of galectin-3 and thyroid transcription factor-1 (TTF-1). Studies demonstrated the positivities of galectin-3 in $100 \%$ of papillary carcinomas, $90-100 \%$ of follicular carcinomas, $50-80 \%$ of medullary carcinomas, $0-33 \%$ of follicular adenomas and $0-$ $38 \%$ of nodular goitres (Beesley et al, 2002). Thyroid transcription factor-1 also expressed $100 \%$ of differentiated follicular tumours including follicular adenoma, follicular carcinoma and papillary carcinoma, but only $25 \%$ of undifferentiated carcinoma of the thyroid (Katoh et al, 2000). These markers were often expressed in benign lesions as well as malignant lesions, being due to the different mechanisms from LAR P-subunit.

We have demonstrated that overexpression of LAR P-subunit specifically occurs in thyroid cancers, particularly in papillary and follicular carcinomas. In addition, of the 128 thyroid follicular adenomas examined, 22 tumours were positive for LAR P-subunit and half of these lesions demonstrated invasive growth into the capsule. The focal immunoreactive patterns of LAR expression in these adenomas suggest that YU1-positive cells have malignant potential and that adenomas expressing LAR P-subunit proteins have a greater propensity to progress to invasive and/or metastatic disease. Little information is available on the signal transducers involved in RET oncogene signalling. However, an increase in LAR may also represent a molecular mechanism for interfering with the kinase activity of RET/PTC and reducing its oncogenic activity. If so, monoclonal antibody YU1 against LAR P-subunit might be useful as both a therapeutic agent as well as a tumour marker. At the very least, it would seem to have a role in further analysis clarifying the role of PTPases in tumorigenesis.

\section{ACKNOWLEDGEMENT}

This work was supported in part by a grant from Fuso Pharmaceutical Industries, Ltd, Japan

\section{REFERENCES}

Beesley MF, McLaren KM (2002) Cytokeratin 19 and galectin-3 immunohistochemistry in the differential diagnosis of solitary thyroid nodules. Histopathology 41: 236-243

Bongarzone I, Butti MG, Coronelli S, Borrello MG, Santoro M, Mondellini P, Pilotti S, Fusco A, Della Porta G, Pierotti MA (1994) Frequent activation of ret protooncogene by fusion with a new activating gene in papillary thyroid carcinomas. Cancer Res 54: 2979-2985

Bukholm IK, Nesland JM, Karesen R, Jacobsen U, Borreusen-Dale AL (1998) E-cadherin and alpha-, beta-, and gamma-catenin protein expression in relation to metastasis in human breast carcinoma. J Pathol 185: $262-266$

Chernoff J (1999) Protein tyrosine phosphatases as negative regulators of mitogenic signaling. J Cell Physiol 180: 173-181

Elson A, Leder P (1995) Protein-tyrosine phosphatase $\varepsilon$. An isoform specifically expressed in mouse mammary tumors initiated by v-Ha-ras or neu. J Biol Chem 270: 26116-26122

Hashimoto N, Feener EP, Zhang WR, Goldstein BJ (1992) Insulin receptor protein-tyrosine phosphatases. Leukocyte common antigen-related phosphatase rapidly deactivates the insulin receptor kinase by preferential dephosphorylation of the receptor regulatory domain. J Biol Chem 267: $13811-13814$
Hinck L, Nathke I, Papkoff J, Nelsen WJ (1994) $\beta$-catenin: a common target for the regulation of cell adhesion by Wnt-1 and Src signaling pathways. Trends Biochem Sci 19: $538-542$

Hunter T (1989) Protein-tyrosine phosphatases: the other side of the coin. Cell 58: $1013-1016$.

Jhiang SM (2000) The RET proto-oncogene in human cancers. Oncogene 19: $5590-5597$.

Kanner SB, Reynolds AB, Parsons JT (1991) Tyrosine phosphorylation of a $120 \mathrm{kD}$ pp60src substrate upon EGF and PDGF receptor stimulation and in polyomavirus middle T-antigen transformed cells. Mol Cell Biol 11: $713-720$

Katoh R, Kawaoi A, Miyagi E, Li X, Suzuki K, Nakamura Y, Kakudo K (2000) Thyroid transcription factor-1 in normal, hyperplastic, and neoplastic follicular thyroid cells examined by immunohistochemistry and nonradioactive in situ hybridization. Mod Pathol 13: 570-576

Krueger NX, Streuli M, Saito H (1990) Structural diversity and evolution of human 2 receptor-like protein tyrosine phosphatase. EMBO J 9: 3241 3252

Li PM, Zhang WR, Golbstein BJ (1996) Suppression of insulin receptor activation by overexpression of the protein-tyrosine phosphatase LAR in hepatoma cells. Cell Signal 8: 467-473 
Liu Y, el-Ashry D, Chen D, Ding IY, Kern FG (1995) MCF-7 breast cancer cells overexpressing transfected c-erbB-2 have an in vitro growth advantage in estrogen-depleted conditions, reduced estrogen-dependence, tamoxifen-sensitivity in vivo. Breast Cancer Res Treat 34: 97-117

Luttrell DK, Lee A, Lansing TJ, Crosby RM, Jung KD, Willard D, Luther M, Rodriguez M, Berman J, Gilmer TM (1994) Involvement of pp60c-src with two major signaling pathways in human breast cancer. Proc Natl Acad Sci USA 91: 83-87

Monaco C, Visconti R, Barone MV, Pierantoni GM, Berlingieri MT, De Lorenzo C, Mineo A, Vecchio G, Fusco A, Santoro M (2001) The RFG oligomerization domain mediates kinase activation and re-localization of the RET/PTC3 oncoprotein to the plasma membrane. Oncogene 20: 599 608

Nam HJ, Poy F, Krueger NX, Saito H, Frederick CA (1999) Crystal structure of the tandem phosphatase domains of RPTP LAR. Cell 97: 449-457

Neel BG, Tonks NK (1997) Protein tyrosine phosphatases in signal transduction. Curr Opin Cell Biol 9: 193-204

Nikiforov YE, Rowland JM, Bove KE, Monforte-Munoz H, Fagin JA (1997) Distinct pattern of ret oncogene rearrangements in morphological variants of radiation-induced and sporadic thyroid papillary carcinomas in children. Cancer Res 57: 1690-1694

Norman SA, Golfinos JG, Scheck AC (1998) Expression of a receptor protein tyrosine phosphatase in human glial tumors. J Neuro-oncol 36: $209-217$

Qiao S, Iwashita T, Furukawa T, Yamamoto M, Sobue G, Takahashi M (2001) Differential effects of leukocyte common antigen-related protein on biochemical and biological activities of RET-MEN2A and RETMEN2B mutant proteins. J Biol Chem 276: 9460 - 9467

Resnik JL, Reichart DB, Huey K, Webster NJ, Seely BL (1998) Elevated insulin-like growth factor I receptor autophosphorylation, kinase activity in human breast cancer. Cancer Res 58: 1159-1164

Santoro M, Dathan NA, Berlingieri MT, Bongarzone I, Paulin C, Grieco M, Pierotti MA, Vecchio G, Fusco A (1994) Molecular characterization of RET/PTC3; a novel rearranged version of the RET proto-oncogene in a human thyroid papillary carcinoma. Oncogene 9: 509-516

Serra PC, Kedersha NL, Fazikas L, Medley Q, Debant A, Streuli M (1995) The LAR transmembrane protein tyrosine phosphatase and a coiled-coil LAR-interacting protein co-localize at focal adhesions. EMBO J 14: 2827 2838

Streuli M, Krueger NX, Ariniello PD, Tang M, Munro JM, Blattler WA, Alder DA, Disteche CM, Saito H (1992) Expression of the receptor-like protein tyrosine phosphatase LAR: proteolytic cleavage and shedding of the CAM-like extracelluar region. EMBO J 11: 897-907

Streuli M, Krueger NX, Hall LR, Schlossman SF, Saito H (1998) A new member of the immunoglobulin superfamily that has a cytoplasmic region homologous to the leukocyte common antigen. J Exp Med 168: $1523-1530$

Streuli M, Krueger NX, Thai T, Tang M, Saito H (1990) Distinct functional roles of the two intracellular phosphatase like domains of the receptorlike protein tyrosine phosphatases LCA and LAR. EMBO J 9: 2399-2407
Symons JR, Levea CM, Mooney RA (2002) Expression of the leukocyte common antigen-related (LAR) tyrosine phosphatase is regulated by cell density through functional E-cadherin complexes. Biochem J 365: $513-519$

Tonks NK, Neel BG (1996) From form to function: signaling by protein tyrosine phosphatases. Cell 87: 365-368

Tsujikawa K, Kawakami N, Uchino Y, Ichijo T, Furukawa T, Saito H, Yamamoto $\mathrm{H}$ (2001) Distinct functions of the two protein tyrosine phosphatase domains of LAR (leukocyte common antigen-related) on tyrosine dephosphorylation of insulin receptor. Mol Endocrinol 15: 271 280

Villa-Moruzzi E, Puntoni F, Bardelli A, Vigna E, De Rosa S, Comoglio PA (1998) Protein tyrosine phosphatase PTP-S binds to the juxtamembrane region of the hepatocyte growth factor receptor Met. Biochemistry 336: $235-239$

Walton KM, Dixon JE (1993) Protein tyrosine phosphatases. Annu Rev Biochem 62: $101-120$

Wang Y, Pallen CJ (1991) The receptor-like protein tyrosine phosphatase HPTP alpha has two active catalytic domains with distinct substrate specificities. EMBO J 10: $3231-3237$

Weier H-UG, Zitzelsberger HF, Hsieh H-B, Sun MV, Wong M, Lersch RA, Yaswen P, Smida J, Kuschnick C, Clark OH (2001) Monitoring signal transduction in cancer: tyrosine kinase gene expression profiling. J Histochem Cytochem 49: 673-674

Wiener JR, Kerns BJ, Harvey EL, Conaway MR, Iglehart JD, Berchuck A, Bast Jr RC (1994) Overexpression of the protein tyrosine phosphatase PTP1B in human breast cancer: association with p185c-erbB-2 protein expression. J Natl Cancer Inst 86: $372-378$

$\mathrm{Xu} \mathrm{Y,} \mathrm{Carpenter} \mathrm{G} \mathrm{(1999)} \mathrm{Identification} \mathrm{of} \mathrm{cadherin} \mathrm{tyrosine} \mathrm{residues} \mathrm{that}$ are phosphorylated and mediate Shc association. J Cell Biochem 75: $264-$ 271

Yang T, Martignetti JA, Massa SM, Longo FM (1999) Leukocyte commonantigen-related tyrosine phosphatase receptor: altered expression of mRNA and protein in the New England Deaconess Hospital rat line exhibiting spontaneous pheochromocytoma. Mol Carcinog 25: 139-149

Yang T, Zhang JS, Massa SM, Han X, Longo FM (2000) Leukocyte common antigen- related tyrosine phosphatase receptor: increased expression and neuronal-type splicing in breast cancer cells and tissue. Carcinogenesis 21: $125-131$

Zhai YF, Beittenmiller H, Wang B, Gould MN, Oakley C, Esselman WJ, Welsch CW (1993) Increased expression of specific protein tyrosine phosphatases in human breast epithelial cells neoplastically transformed by the new oncogene. Cancer Res 53: $2272-2278$

Zhang WR, Hashimoto N, Ahmad F, Ding W, Goldstein BJ (1994) Molecular cloning and expression of a unique receptor-like proteintyrosine-phosphatase in the leukocyte-common-antigen-related phosphate family. Biochem J 302: 39-47

Zheng XM, Wang Y, Pallen CJ (1992) Cell transformation and activation pp60 ${ }^{c-s r c}$ by overexpression of a protein tyrosine phosphatase. Nature (London) 359: 336-339 